\title{
Arnel Development Co. v. City of Costa Mesa : Rezoning by Initiative and Landowners' Due Process Rights
}

The propriety of the use of the initiative in connection with zoning decisions has been disputed in California for over fifty years. ${ }^{1}$ In Arnel Development Co. v. City of Costa Mesa, ${ }^{2}$ the California Supreme Court decided that the initiative could be used to zone or rezone any property, regardless of its size. The court based its holding on the theory that any zoning or rezoning is a legislative act, and therefore a proper subject for initiative. ${ }^{3}$

The question in Arnel arose at the confluence of two iniportant rights. First, the California Constitution reserves the power of initiative in the people as legislators, and thus enables the direet passage of any measure so long as that measure is a proper subject for legislative determination. ${ }^{4}$ Second, both the California ${ }^{5}$ and federal ${ }^{6}$ Constitutions guarantee that no one will be deprived of property without due process of law. The conjunction of these two doctrines presents hard policy questions. Answering thein requires an examination of the policies behind allowing legislation-by-initiative and the desire for procedural fairness in land use decisions.

This Note argues that the Arnel court should have disallowed the use of the initiative for zoning or rezoning property on due process grounds. The court reached an incorrect result because, in its concern

1. See, e.g., Hurst v. City of Burlingame, 207 Cal. 134, 277 P. 308 (1929), and cases discussed infra Part II.

2. 28 Cal. 3d 511, 620 P.2d 565, 169 Cal. Rptr. 904 (1980).

3. Id. at $516-17,620$ P.2d at 568, 169 Cal. Rptr. at 907.

4. CAL. Const. art. II, \& 8. See infra notes $32-42$ and accompanying text.

5. CAL. Const. art. I, \& 7(a).

6. U.S. CoNST. amends. V, XIV. Since Costa Mesa is a general law city, its zoning procedures must conform to those laid out in the state zoning laws. See CAL. Gov'T CODE $\$ \S 65800-$ 65912 (West 1966 \& Supp. 1981).

A charter city, however, does not operate under state law. The constitution empowers a city to control its own government through adoption of a charter by vote of its electors. $C_{A L}$. Const. art. XI, \&3. Thus, the city charter controls with respect to municipal affairs and supersedes any inconsistent state laws in that area. CAI. ConST. art. XI, \&5. The charter may allow a city, subject only to such limitations as appear in the charter itself, to make and enforce all regulations with respect to municipal affairs. In all other matters, state law controls. A city's charter, then, is often regarded as its own constitution. See, e.g., Brown v. City of Berkeley, 57 Cal. App. 3d 223, 231, 129 Cal. Rptr. 1, 4 (1st Dist. 1976). 
with labels and semantic neatness, it relied on a rule developed to define the proper standard for judicial review of decisions made by administrative bodies. It thereby elevated the form of a rezoning decision over its substance and effect; the result is a deprivation of property rights that violates the due process guarantees of the federal and state constitutions. Part I of this Note sets out the facts, holding, and opinions in Arnel. Part II presents the legal background of several important aspects of the case. Finally, Part III analyzes the California Supreme Court's decision and suggests a inore appropriate inethod, involving the balancing of several factors, to be used in reviewing zoning by imitiative.

\section{I \\ THE CASE}

\section{A. The Facts}

The Costa Mesa imitiative at issue in Arnel rezoned 67.6 acres of undeveloped land, part of which was leased by plaintiff Arnel Development Company; the balance was owned by two others. ${ }^{7}$ Before passage of the imitiative, Costa Mesa's general plan designated part of the affected land as low-density residential and part as medium-density residential. In late 1976, the city approved Arnel's specific plan to construct a relatively high-density development intended for inoderate income housing, ${ }^{8}$ and rezoned 50 acres to accommodate that development. Final approvals of the project and of a tentative tract inap followed. Shortly thereafter, some Costa Mesa residents circulated an imitiative petition to rezone the property again, so as to prohibit the planned development. ${ }^{9}$ The ineasure was placed on the mumcipal ballot, and it passed in $1978 .{ }^{10}$ The new zoning required that the entire 67.6 acre parcel be used for single-family residences. ${ }^{11}$ Thereafter, the

7. 28 Cal. 3d at $514 \&$ nn.1 \& 2, 620 P.2d at $566 \&$ nn.1 \& 2, 169 Cal. Rptr. at $905 \&$ nn.1 \& 2. One of the other owners, South Coast Plaza, filed a separate action and the cases were consolidated for trial. A third party, Roberts, owned 4.6 of the 67.6 acres rezoned by the initiative but did not file suit challenging the initiative's validity. Id. at 515, 620 P.2d at 567, 169 Cal. Rptr. at 906.

8. Specifically, Arnel planned to build 127 single-family residences and 539 apartment units. Id. at 513, 620 P.2d at 566, 169 Cal. Rptr. at 905.

9. Before the election, the promulgators of the rezoning initiative agreed with the property owners and wished to remove the rezoning measure from the ballot. This could not be done, however, and the election proceeded. Clerk's Transcript 971, Exhibit 69, p. 3, lines 15-16.

10. The ineasure was approved in the March 7, 1978 municipal election. It passed by a narrow majority: 4,295 to 3,901 . There are 36,000 registered voters in the city of Costa Mesa, whose population is over 70,000. Clerk's Transcript $822 \mathrm{~L}$.

11. Part of the record before the court indicated that the single-family residential zoning was chosen simply because it was the most restrictive alternative available. Clerk's Transcript 971, Exhibit 69, p. 2, line 22 through p. 3, line 4. 
city refused to process any further steps in Arnel's attempt to continue development.

Arnel Developinent Company brought suit, praying for mandate, injunctive relief, and declaratory rehef. ${ }^{12}$ The trial court upheld the vahidity of the initiative. The court of appeal reversed, holding that the rezoning was adjudicatory in nature and therefore an iniproper subject for initiative. The court of appeal reasoned that the change was not generally apphicable, but apphied only to the specific parcels. On its own motion, the California Supreme Court transferred the case for further consideration. ${ }^{13}$

\section{B. The Opinions}

Justice Tobriner, writing for the majority ${ }^{14}$ of the California Supreme Court, held that the court of appeal erred in finding that the rezoning of a specific sinall parcel of privately owned property was an improper subject for initiative. While the court agreed that only legislative, and not executive or administrative, power is exercisable through direct legislation, it found that the enactment of any ineasure zoning or rezoning property is a legislative act, regardless of the size of the parcel. The majority derived this rule from prior California cases, some of which involved the enactment of zoning measures by initiative ${ }^{15}$ and some of which concerned the standard of judicial review applicable to decisions made by administrative bodies. ${ }^{16}$ The court drew from these cases a strict rule that all zoning ordinances and ainend-

12. $28 \mathrm{Cal} .3 \mathrm{~d}$ at $514 \mathrm{n} .2,620$ P.2d at $566 \mathrm{n} .2,169$ Cal. Rptr. at $905 \mathrm{n} .2$.

13. Following its decision in Amel, the California Supreme Court retransferred the case to the court of appeal for consideration of issues not addressed in the higher court's opinion. Id. at 514, 620 P.2d at 567, 169 Cal. Rptr. at 906. The court of appeal, speaking through Justice Kaufman, once again held that the rezoning was invalid, this time on the ground that the initiative ordinance was arbitrary and discriminatory and therefore exceeded the city's police power. See Arnel Dev. Co. v. City of Costa Mesa, 126 Cal. App. 3d 330, 333, 178 Cal. Rptr. 723, 725 (4th Dist. 1981) [heremafter cited as Amel II]. The court reasoned that since more than 18 months of land use planning and over 30 public hearings had been nsed in making the decision to allow Arnel to construct its proposed development, a rezoning passed specifically to prohibit such development, in the absence of a clange of circumstances, must be arbitrary and discriminatory. Moreover, the court said, had the city council instead of the voters undertaken the same rezoning, it is clear that its action would have been held invalid. Id. at 337, 178 Cal. Rptr. at 727. The court went on to say that the initiative rezoning was also unrelated to the regional public welfare and thus invalid as an excessive use of the police power. Id. It appears, then, that Arnel finally won the developinent war, the interlude in the supreme court was inerely a lost battle.

14. Bird, C.J., Tobriner, Mosk, Newinan, Manuel, JJ.

15. See, eg., Associated Honnebuilders of the Greater Eastbay, Inc. v. City of Livernore, 18 Cal. 3d 582, 557 P.2d 473, 135 Cal. Rptr. 41 (1976); San Diego Bldg. Contractors' Ass'n v. City Council of San Diego, 13 Cal. 3d 205, 529 P.2d 570, 118 Cal. Rptr. 146 (1974); Bayless v. Limber, 26 Cal. App. 3d 463, 102 Cal. Rptr. 647 (2d Dist. 1972).

16. See, e.g., Lockard v. City of Los Angeles, 33 Cal. 2d 453, 202 P.2d 38 (1949); Toso v. City of Santa Barbara, 101 Cal. App. 3d 934, 162 Cal. Rptr. 210 (2d Dist. 1980); Hilton v. Board of Supervisors, 7 Cal. App. 3d 708, 86 Cal. Rptr. 754 (2d Dist. 1970). 
ments thereto are legislative in nature, while other land use changes, such as the granting of variances, special use permits, and tentative subdivision maps, are invariably outside of the legislative sphere. ${ }^{17}$

The majority found two of the California Supreme Court's previous decisions particularly persuasive. The 1927 case of Dwyer v. City Council of Berkeley ${ }^{18}$ involved the rezoning of a single parcel of land comprising a very small portion of the city of Berkeley. The suprene court upheld the submission of this zoning change to a referendum on the ground that it affected all of the residents of the city alike. ${ }^{19}$ The second case, Johnston v. City of Claremont, ${ }^{20}$ also allowed the amendment of a zoning ordinance to be referred to the voters. Although its decision was based on other grounds, the court in Johnston, statcd that the amendinent of a legislative act is itself legislative im nature. ${ }^{21}$

The Arnel majority went on to reject the plaintiffs' contention that the use of the initiative had operated to deprive them of their constitutionally guaranteed due process rights. The court dismissed the federal due process claim by citmg the Umited States Supreine Court's decision in Eastlake v. Forest City Enterprises, ${ }^{22}$ which held that subjecting a zoning decision to referendum was not an unconstitutional delegation of legislative power. ${ }^{23}$ Turning to the state due process claim, the majority reiterated that rezoning is legislative in nature and that due process guarantees do not apply to exercises of general legislative power. The court here relied on the 1974 decision im San Diego Building Contractors'Association v. City Council of San Diego, ${ }^{24}$ in which a thirtyfoot height restriction on future coastline building enacted by initiative was upheld on the ground that it was within the scope of legislative power.

Addressing plaimtiffs' policy arguments, the court next rejected their contention that procedural due process guarantees attach to at least those zoning amendments that affect small tracts with few owners. The majority found that a rule based on tract size or number of owners would be extremely difficult to formulate and apply, and that therefore these factors should be deemed irrelevant to the determination of whether a given zoning decision must be accompanied by procedural safeguards. ${ }^{25}$ Furthermore, the majority argued, the Costa Mesa initia-

17. $28 \mathrm{Cal} .3 \mathrm{~d}$ at $518,620 \mathrm{P.} 2 \mathrm{~d}$ at $569,169 \mathrm{Cal}$. Rptr. at 908.

18. $200 \mathrm{Cal} .505,253$ P. 932 (1927).

19. Id at 515,253 P. at 936 .

20. 49 Cal. $2 \mathrm{~d} 826,323$ P.2d 71 (1958).

21. Id at 835,323 P.2d at 76 . See also infra note 63 and accompanying text.

22. 426 U.S. 668 (1976).

23. See infra text accompanying notes 117-124.

24. 13 Cal. 3d 205, 529 P.2d 570, 118 Cal. Rptr. 146 (1974).

25. $28 \mathrm{Cal} .3 \mathrm{~d}$ at 522-23, 620 P.2d at 572, 169 Cal. Rptr. at 911 . 
tive was sensibly seen as a legislative decision because it was unlikely that voters would ever attempt to initiate legislation so limited in scope as to be outside of the legislative sphere: only measures of critical intportance to the future development of the city would inotivate them to expend the time and money necessary to invoke the initiative process. ${ }^{26}$ Fimally, the court found that adherence to a strict rule that amendments to zoning ordinances are always legislative promotes judicial economy and discourages litigation by making the outcone predictable. ${ }^{27}$

In dissent, Justice Richardson, joined by Justice Clark, argued that the rezoning of a small parcel privately owned by a few individuals is in the nature of an adjudicative decision, and, therefore, the owners of such property must be given notice and the opportunity to be heard before the change is enacted ${ }^{28}$ Under this analysis, it follows that the initiative was an iniproper device for rezoning suclı parcels, and its use had to be invalidated. Richardson distinguished the decision in San Diego Building Contractors'Association on the ground that the San Diego initiative enacted a rule of general application to which due process requirements did not attacl. In contrast, the Costa Mesa initiative had a particularized effect on only a few individuals and was therefore adjudicative.

Justice Richardson did not agree with the majority's holding that prior cases had established an unwavering rule making all zoning amendments legislative; rather, he argued, courts must look to the substance and not the form of the action when making the characterization. $^{29}$ For precedential support the dissenters relied on Horn v. County of Ventura. ${ }^{30}$ In Horn, without referring to any strict, formalistic rule of characterization, the Califorina Supreme Court held that decisions involving the application of general standards to specific property, affecting relatively few persons, and decided on the facts of the particular case, were nonlegislative in nature. ${ }^{31}$ Such decisions, in turn, mandated that a specific individual could not be deprived of property rights without first being afforded some procedural safeguards. Ironclad rules that elevate form over substance in the interest of judicial efficiency, the dissenters concluded, have no place in the consideration of due process claims.

26. Id. at 524, 620 P.2d at 573, 169 Cal. Rptr. at 911-12.

27. Id. at 523, 620 P.2d at 572-73, $169 \mathrm{Cal}$. Rptr. at 912 .

28. Id. at 526,620 P.2d at 574, 169 Cal. Rptr. at 913 (Richardson, J., dissenting).

29. Id. at 525, 620 P.2d at 574, $169 \mathrm{Cal}$. Rptr. at 913. Justice Richardson also noted the anomaly that if Amel lrad applied for a variance, the decision would, under the majority's rule, be nonlegislative; but since the voters of Costa Mesa, not the owners, wanted the cliange, it was classified as legislative. Id. at 527-28,620 P.2d at 575, 169 Cal. Rptr. at 914.

30. 24 Cal. 3d 605, 596 P.2d 1134, 156 Cal. Rptr. 718 (1979).

31. Id. at 613-14, 596 P.2d at 1138, 156 Cal. Rptr. at 722-23. 
II

\section{LEGAL BACKGROUND}

\section{A. The Rights of Initiative and Referendum}

The California Constitution reserves to the people the rights of initiative and referendum. ${ }^{32}$ The initiative provision allows the statewide or local electorate to enact legislation directly, bypassing its elected representatives. For local initiatives, ten percent of the voters may, by signing petitions, place a measure on the ballot for adoption or rejection by the entire electorate in the next regular inunicipal election. ${ }^{33}$ This power to initiate law extends to both statutes and constitutional amendments. ${ }^{34}$

The referendum, by contrast, allows the voters to pass on the desirability of a measure already enacted by the elected legislative body. ${ }^{35}$ Within thirty days following passage of a measure, if ten percent of the voters request a referendum by petition, the ineasure will be subjected to the scrutiny of the electorate. ${ }^{36}$ The referendum aunounts to a people's veto power over acts of representative bodies. ${ }^{37}$ It is an oft-repeated inaxim that the powers of initiative and referendum should be construed liberally so that they may be found validly exercised in as many situations as possible. ${ }^{38}$

32. Cal. Const. art. IV, \& 1. See also Cal. Elec. Code $\$ \$ 3500-5025$ (West $1977 \&$ Supp. 1982). The constitution provides that not only the electors of the state, but also the voters of any general law city or county, may exercise the rights of initiative and referendum. CAL. Const. art. II, $\$ 88,9$. This section is made expressly inapplicable to charter cities, whose voters may reserve to themselves the powers of initiative and referendum but must do so in the city charter. For a more detailed discussion of the difference between the two types of cities, see supra note 6 . For a discussion of the influence of money on the referendum and initiative processes, see Note, Citizens Against Rent Control v. City of Berkeley: Constitutionality of Limits on Contributions in Ballot Measure Campaigns, 69 CALIF. L. REv. 1001, 1011-13 (1981).

33. See Cal. Elec. Code $\S 4011$ (West Supp. 1982). The number of signatures required differs for special elections. Id $\$ 4010$.

34. CAL. Const. art. II, $\S 8$. It is beyond the scope of this Note whether the initiative power is being too permissively construed, as some liave suggested. "[T]here is growing concern among some officials that [the initiative and referendum] are beginning to run amok." Is the Referendum Process Out of Hand? San Francisco Chron., Feb. 20, 1982, at 28, col. 2.

35. The constitution excepts "urgency statutes, statutes calling elections, and statutes providing for tax levies or appropriations for usual current expenses of the State." CAL. CONST. art. II, \$9.

36. See CAL. Elec. Code $\$ 4051$ (West 1977).

37. City of Eastlake v. Forest City Enters., Inc., 426 U.S. 668, 673 (1976).

38. See, e.g., Amador Valley Joint Umion High School Dist. v. State Bd. of Equalization, 22 Cal. 3d 208, 219-20, 583 P.2d 1281, 1283-84, 149 Cal. Rptr. 239, $241-42$ (1978) (upholding validity of Proposition 13); Associated Homebuilders of the Greater Eastbay, Inc. v. City of Livcrmore, 18 Cal. 3d 582, 591, 557 P.2d 473, 477, 135 Cal. Rptr. 41, 45 (1976) (uplolding local initiative restricting issuance of building permits); Committee for Sewer Referendum v. Humboldt Bay Wastewater Auth., 77 Cal. App. 3d 117, 122, 143 Cal. Rptr. 463, 466 (1st Dist. 1978) (liberally construing procedural requirements for filing referendum petitions). But $c f$. Mills v. County of Trinity, 108 Cal. App. 3d 656, 660, 166 Cal. Rptr. 674, 676 (3d Dist. 1980) (urging liberal construction, yet 
There are, however, some fairly well-defined limitations on these powers. The most important is that the initiative may not contravene paramount laws such as the mandates of the state and federal constitutions. $^{39}$ In addition, three judicial limitations on the use of direct legislation have developed. First, only legislative decisions are properly undertaken by imitiative or subjected to referendum; administrative decisions entrusted to local governing bodies are beyond the scope of the direct legislation power. ${ }^{40}$ Second, both powers are exercisable only on matters of citywide concern, not on questions affecting only a small segment of the community. ${ }^{41}$ Third, the people's power to initiate legislation is limited to measures that the legislative body itself could pass. ${ }^{42}$ Nunierous challenges have used these limitations to attack the validity of local electorates' uses of the initiative or referendum to amend zoning ordinances.

\section{B. Challenges to Use of the Initiative in Zoning}

The interaction of the people's constitutionally reserved power to initiate legislation with the due process embodied in the carefully structured state zoning laws $\mathrm{s}^{43}$ has engendered much litigation challenging the propriety of allowing the public to decide land use questions. Two separate clallenges to zoning by initiative have been advanced.

\section{The Compatibility Challenge}

The first basis for attacking zoning initiatives, the compatibility challenge, ${ }^{44}$ posits that since the process of direct legislation does not

concluding that "special taxes" under Proposition 13 does not include reasonable fees for land use regulatory activities).

39. See, e.g., Citizens Against Rent Control v. City of Berkeley, 102 S. Ct. 434 (1981) (invalidating ordinance adopted by local initiative as violative of first amendment); Hardie v. Eu, $18 \mathrm{Cal}$. 3d 371, 556 P.2d 301, 134 Cal. Rptr. 201 (1976) (invalidating part of Proposition 9, the Political Reform Act of 1974, as violative of first amendment), cert. denied, 430 U.S. 969 (1977); Comment, The Scope of the Initiative and Referendum in California, 54 CALIF. L. REv. 1717, 1724 (1966).

40. See also infra notes $52-57$ and accompanying text.

41. On the other hand, a municipal ordinance cannot be enacted by initiative where state regulation of the area is so pervasive as to be deemed preemptive. See, e.g., Redevelopinent Agency of Berkeley v. City of Berkeley, 80 Cal. App. 3d 158, 143 Cal. Rptr. 633 (1st Dist. 1978) (initiative to halt redevelopment held invalid on ground that redevelopment is a statewide concern and that power over it has been given to local governing bodies); Friends of Mt. Diablo v. County of Contra Costa, 72 Cal. App. 3d 1006, 139 Cal. Rptr. 469 (1st Dist. 1977) (rezoning of single property challenged by initiative held invalid on the ground that development is a matter of statewide concern as to which the legislature had given exclusive power to the local governing body).

42. See Note, Judicial Limitations on the Initiative and Referendum in California Municipalities, 17 Hastings L.J. 805, 806 (1966).

43. See Cal. Gov't Code $\$ \S 65853-65857$ (West Supp. 1982).

44. The term "coinpatibility" was coined by Professor Glein1 in Glenn, State Law Limitations on the Use of Initiatives and Referenda in Connection With Zoning Amendments, $51 \mathrm{~S}$. CAL. L. REv. 265 (1978). 
include the detailed procedural steps required by state zoning laws, use of the initiative is invalid. In the 1929 case of Hurst $v$. City of Burlingame, ${ }^{45}$ the California Supreme Court accepted this arguinent and disallowed zoning by initiative in general law cities like Costa Mesa. ${ }^{46}$ The Hurst decision was based on the incompatibility of the initiative procedure with that of the zoning law, but included dicta to the effect that the proccdural safeguards inandated by state law are constitutionally required. ${ }^{47}$

A long line of cases following Hurst accepted the preinise that the state zoning act is a special and particularized law taking precedence over the state initiative process, which is general in scope. ${ }^{48}$ But in 1976, the California Supreme Court reversed itself. In Associated Homebuilders of the Greater Eastbay, Inc. v. City of Livermore, ${ }^{49}$ the court leeld that the procedural requireenents of the state zoning law do not apply to legislative zoning ordmances enacted by initiative in general law cities. ${ }^{50}$ The Livermore court also disapproved the Hurst dictum that the state zoning laws contained constitutionally mandated procedural steps. Livermore thus made the compatibility challenge obsolete. $^{51}$

45. 207 Cal. 134, 277 P. 308 (1929).

46. Costa Mesa is a general law city. $28 \mathrm{Cal} .3 \mathrm{~d}$ at $515 \mathrm{n} .4,620$ P.2d at $567 \mathrm{n} .4,169 \mathrm{Cal}$. Rptr. at 906 n.4. In California, a city may be organized in either of two ways: under general law, or under a charter. CAL. CoNST. art. XI, \$§ 5, 7; CAL. Gov'T CODE $\$ \S 34100-34102$ (West 1968). The difference is pertinent in determining what law governs municipal affairs. Electors in general law cities have the right to pass on the composition of their local government only within the boundaries of the state constitution and the statutes enacted by the legislature. Williams v. City of San Carlos, 233 Cal. App. 2d 290, 295, 43 Cal. Rptr. 486, 489 (1st Dist. 1965). General law cities are "creations of the state and as such are parts of the machinery by which the state conducts its governmental affairs." Id. This means that a general law city operates under the rules made by the legislature and is generally limited to powers expressly conferred. See Irwin v. City of Manhattan Beach, 65 Cal. 2d 13, 20, 415 P.2d 769, 773, 51 Cal. Rptr. 881, 885 (1966).

47. $207 \mathrm{Cal}$. at $141,277 \mathrm{P}$. at 311.

48. See, e.g., Johnston v. City of Claremont, 49 Cal. 2d 826, 323 P.2d 71 (1958); Taschner v. City Council, 31 Cal. App. 3d 48, 107 Cal. Rptr. 214 (4th Dist. 1973); People's Lobby, Inc. v. Board of Supervisors, 30 Cal. App. 3d 869, 106 Cal. Rptr. 666 (1st Dist. 1973); Laguna Beach Taxpayers Ass'n v. City Council, 187 Cal. App. 2d 412, 9 Cal. Rptr. 775 (4th Dist. 1960). The language in all of these cases relying on Hurst was later expressly disapproved by the supreme court. See Associated Homebuilders of the Greater Eastbay, Inc. v. City of Livermore, 18 Cal. 3d at $596 \mathrm{n} .14,557$ P.2d at $480 \mathrm{n} .14,135$ Cal. Rptr. at 48 n.14.

49. $18 \mathrm{Cal} .3 \mathrm{~d} 582,557$ P.2d 473, 135 Cal. Rptr. 41 (1976).

50. The compatibility challenge, even during the reign of Hurst and its progeny, was never successfully asserted in a case involving a charter city. The reason is that the city charter itself, if it reserves the power of initiative to the people, allows passage of all municipal legislation by direct measures. See Duran v. Cassidy, 28 Cal. App. 3d 574, 104 Cal. Rptr. 793 (5th Dist. 1972); Bayless v. Limber, 26 Cal. App. 3d 462, 102 Cal. Rptr. 647 (2d Dist. 1972).

51. See Glenn, supra note 44 , at 285. 


\section{The Characterization Challenge}

The characterization challenge ${ }^{52}$ begins with the rule that the powers of initiative and referendum apply only to "legislative," and not "executive" or "administrative," acts. ${ }^{53}$ In other words, the people's power to initiate legislation, while coextensive with the governing body's power to nake law, does not have the same reach as the governing body's other powers. A characterization challenge argues that the enactment of a zoning ordinance is an administrative function and hence not suitable for direct legislation. The rationale for this assertion is that administrative decisions are those which necessitate particularized factinding and are subject to due process requirements, which cannot be fulfilled by the direct legislation process.

The California Supreme Court accepted the characterization analysis but rejected its urged apphication in San Diego Building Contractors'Association v. City Council of San Diego. ${ }^{54}$ In San Diego, the court agreed that administrative acts are not subject to the initiative process, but held that enactment of a thirty-foot height limitation on buildings to be erected along the city's coastline was an exercise of general legislative power. ${ }^{55}$ Thus, the height limitation was properly enacted by initiative, as it was not subject to any due process requirements.

The lesson of San Diego is that the initiative is an accepted tool in some zoning matters. ${ }^{56}$ Whether a given land use decision is a proper subject for direct legislation turns on whether it is deeined to be a decision that the local governing body could make in its legislative capacity without adhering to the procedures required in administrative actions, which include giving those affected solne notice and hearing. A necessary iniphication of the court's acceptance of the characterization analysis, however, is that some way of distinguishing legislative from nonlegislative acts ${ }^{57}$ exists. The purported critical distinction poses a

52. The terminology is, again, Professor Glenn's; see id. at 294.

53. See Sinnson v. Hite, 36 Cal. 2d 125, 129, 222 P.2d 225, 228 (1950).

54. 13 Cal. 3d 205, 529 P.2d 570, 118 Cal. Rptr. 146 (1974), appeal dismissed, 427 U.S. 901 (1976).

55. Id. at $211,529 \mathrm{P} .2 \mathrm{~d}$ at $573,118 \mathrm{Cal}$. Rptr. at 149. See also infra note 98.

56. For example, the initiative would still not be a proper method for granting a variance or a use permit. Id. at 212 \& n.5, 529 P.2d at 574 \& n.5, 118 Cal. Rptr. at 150 \& n.5.

57. This Note uses the term "nonlegislative act" to encompass the plethora of labels courts have used in this area. Thus, an act which is not legislative may be "administrative" (see Toso v. City of Santa Barbara, 101 Cal. App. 3d 934, 942, 162 Cal. Rptr. 210, 214 (2d Dist.), cert. denied, 449 U.S. 901 (1980)), "adjudicative" (see Horn v. County of Ventura, 24 Cal. 3d 605, 612, 596 P.2d 1134, 1137, 156 Cal. Rptr. 718, 721 (1979)), or even "quasi-judicial" (see Topanga Ass'n for a Scenic Community v. County of Los Angeles, 11 Cal. 3d 506, 517, 522 P.2d 12, 19, 113 Cal. Rptr. 836,843 (1974)). The difference in terminology, at least as it applies to the proper scope of the initiative, is less inportant than the sinupler rule that the initiative power is coextensive with the power of the legislature (or any body acting in a legislative capacity). Any act classified as outside of the legislative sphere, whether because it only applies established policies (administrative) or 
simple question: how do we know a legislative act when we see one?

\section{Distinguishing Legislative From Nonlegislative Acts}

\section{Development of the Distinction in California}

Since the energence of the characterization analysis as the sole means of judging the vahdity of a zoning initiative is a fairly recent development, ${ }^{58}$ the analytical distinction between legislative and nonlegislative acts has been developed largely outside of the initiative context. It has been used mainly to assist courts in determining appropriate standards of review and in resolving due process clainis.

\section{a. The Standard of Review Context}

Most cases that have labeled acts as legislative or nonlegislative have done so for the purpose of determining the proper standard of judicial review. Several such cases have held that a city council's amendment of a zoning ordinance is a legislative act, reviewable by ordmary mandamus. ${ }^{59}$ Others have held that grants of variances and conditional use permits are administrative acts ${ }^{60}$ reviewable by administrative inandamus. ${ }^{61}$

The analyses courts use to make these distinctions are not consistent. Several cases have cited the 1958 case of Johnston v. City of Clare-

because those affected by it are entitled to notice and hearing before its enactment (adjudicative), cannot be accomplished by initiative. As the critical distinction is only between those acts which are legislative and those which are not, "nonlegislative" is a clearer way to refer to the latter. See also Wolfstone, The Case for a Procedural Due Process Limitation on the Zoning Referendum: City of Eastlake Revisiled, 7 ECOLOGY L.Q. 51, 87-88 (1978).

58. It has achieved this status due to the combined effect of the 1974 San Diego holding that accepted the characterization analysis and the 1976 Livermore decision that rejected the compatibility challenge. See supra notes $45-57$ and accompanying text.

59. See, e.g., Toso v. City of Santa Barbara, 101 Cal. App. 3d 934, 162 Cal. Rptr. 210 (2d Dist. 1980) (denial of developer's application for rezoning was legislative act reviewable by ordinary mandamus); Karlson v. City of Camarillo, 100 Cal. App. 3d 789, 161 Cal. Rptr. 260 (2d Dist. 1980) (two amendments, changing the zonings of a 132.5-acre parcel and a 10-acre parcel, respectively, held legislative acts); Tandy v. City of Oakland, $208 \mathrm{Cal}$ App. 2d 609, 25 Cal. Rptr. 429 (1st Dist. 1962) (court cannot compel rezoning of property simce it is a legislative act).

60. See, eg., Topanga Ass'n for a Scenic Community v. County of Los Angeles, 11 Cal. 3d 506, 522 P.2d 12, 113 Cal. Rptr. 836 (1974); Viso v. State, 92 Cal. App. 3d 15, 21, 154 Cal. Rptr. 580, 584 (3d Dist. 1979).

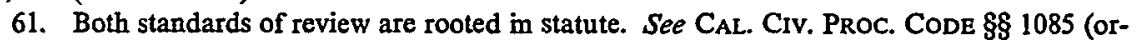
dimary mandamus), 1094.5 (administrative mandamus) (West Supp. 1982). In review by ordmary mandamus, a trial court must determine whether the action attacked was arbitrary and capricious. See Mountain Defense League v. Board of Supervisors, 65 Cal. App. 3d 723, 727, 135 Cal. Rptr. 588, 589 (4th Dist. 1977). In review by administrative mandamus, the trial court either reviews the record below to see if the conclusion was supported by substantial evidence, or uses its independent judgment to review the decision being attacked. Independent judginent is employed only when a fundamental vested right is involved. See Strumsky v. San Diego County Employees Retirement Ass'n, 11 Cal. 3d 28, 520 P.2d 29, 112 Cal. Rptr. 805 (1974); Bixby v. Pierno, 4 Cal. 3d 130, 481 P.2d 242, 93 Cal. Rptr. 234 (1971). 
mont ${ }^{62}$ which held that a zoning amendment was properly subjected to referendum, for its dictum that since the enactment of a city's general zoning ordmance is legislative in nature, any amendment thereto must also be legislative. ${ }^{63}$ Others have claimed to bypass such formalisin and have attempted to find soinething inherent in either the decisionmaking processes or the decisions themselves that distinguishes legislative from administrative acts. ${ }^{64}$ In Selby Realty Co. v. City of San Buenaventura, ${ }^{65}$ the Califorma Supreme Court held that the adoption of a general plan is a legislative act because it is a decision that affects all citizens in a similar way. ${ }^{66}$ The Fourth District Court of Appeal has stated that legislative action creates a rule for all future cases, whereas quasi-judicial, hence nonlegislative, action determines specific rights under existing law with regard to a specific fact situation. ${ }^{67}$

There is a tension, which has gone unrecognized by the courts, between the strict Johnston dictum and the approach that purports to look at the nature, instead of the form, of the act. In practice, however, this tension is largely irrelevant, since courts determining the proper standard of review for amendments to legislation have tended to look to form alone. ${ }^{68}$ The practical result in the standard of review context, then, is to give all zoning amendments the less stringent review ac-

62. 49 Cal. 2d 826, 834-35, 323 P.2d 71, 76 (1958).

63. See, e.g., Topanga Ass'n for a Scenic Community v. County of Los Angeles, 11 Cal. 3d 506, 522 P.2d 12, 113 Cal. Rptr. 836 (1974); Toso v. City of Santa Barbara, 101 Cal. App. 3d 934, 162 Cal. Rptr. 210 (2d Dist. 1980); Hilton v. Board of Supervisors, 7 Cal. App. 3d 708, 86 Cal. Rptr. 754 (2d Dist. 1970).

The proposition derived from Johnston was in fact dictum. Johnston was decided during the reign of the compatibility analysis, and its actual holding was that the referendum is compatible with state zoning laws because the required procedures are carried out before the change is submitted to the people. See Fishman v. City of Palo Alto, 86 Cal. App. 3d 506, 511, 150 Cal. Rptr. 326, 329 (1st Dist. 1978).

64. The classic statement of the distinction was made in a different context in McKevit $v$. City of Sacramento, 55 Cal. App. 117, 203 P. 132 (Ist Dist. 1921):

Acts constituting a declaration of public purpose, and making provisions for ways and means of its accomplishment, may be generally classified as calling for the exercise of legislative power. Acts which are to be deened as acts of administration, and classed among those governmental powers properly assigned to the executive department, are those which are necessary to be done to carry out legislative policies and purposes already declared ....

Id. at 124,203 P. at 136.

65. 10 Cal. 3d 110, 117-18, 514 P.2d 111, 115-16, 109 Cal. Rptr. 799, 803-04 (1973).

66. See also Karlson v. City of Camarillo, 100 Cal. App. 3d 789, 799, 161 Cal. Rptr. 260, 265 (2d Dist. 1980).

67. Mountain Defense Leagne v. Board of Supervisors, 65 Cal. App. 3d 723, 729, 135 Cal. Rptr. 588, 590 (4th Dist. 1977).

Where a local governmental body makes a decision containing elements of both adjudicatory and legislative action, the "dommant concern" prevails. See City of Rancho Palos Verdes v. City Council, 59 Cal. App. 3d 869, 882-83, 885, 129 Cal. Rptr. 173, 178-80 (2d Dist. 1976).

68. See cases cited supra note 63. 
corded the legislative act. ${ }^{69}$ Adherence to the dictum in Johnston that any amendment to a legislative act is itself legislative has continued, largely without analysis.

\section{b. The Due Process Context}

Determining when the owner of affected property inust be given notice and the opportumity to be heard before being deprived of some interest in that property has also led courts into the realm of the legislative-nonlegislative distinction. The courts have asked whether the action taken is in the nature of a nonlegislative adjudication of the rights of specific parties; if it is, the Constitution guarantees those parties a panoply of due process rights, includimg notice and the opportumity to be heard. ${ }^{70}$

The Umited States Supreme Court made the classic statement of the difference between legislative and nonlegislative acts in Bi-Metallic Investment Co. v. State Board of Equalization. ${ }^{71}$ Justice Holmes rejected plaintiffs' contention that all individuals have a constitutional right to be heard before a decision im which all are equally concerned can be made. "Where a rule of conduct apphes to more than a few people it is impracticable that everyone should have a direct voice in its adoption." ${ }^{72}$ Holmes made it clear, however, that where an act affects "a relatively small number of persons . . . upon individual grounds,"73 those persons inust be afforded notice and hearing.

Since notice and an opportumity to be heard are statutorily mandated in most zoning decisions, ${ }^{74}$ few California courts have found it necessary to analyze due process rights by resorting to the Bi-Metallic standard. One exception, however, was Horn $v$. County of Ventura ${ }^{75} \mathrm{~m}$ which the California Supreme Court held that the approval of a tentative subdivision map was adjudicative, and hence nonlegislative. The court cited Holmes' language in Bi-Metallic ${ }^{76}$ and defined "the exercise of judgment, and the careful balancing of conflictimg interests" as the hallmark of the adjudicative process. ${ }^{77}$ It is significant that here, in the

69. "Even when a zoning amendment concerns only one parcel of land, form prevails over substance; on judicial review the court assumes the deferential posture associated with legislative decisions." Wolfstone, supra note 57 , at 82.

70. Exactly what constitutes due process varies and will be further discussed below. See infra notes 130-155 and accompanying text. Generally, however, notice and opportunity for a hearing before the decision is made are the minimun. See infra note 152 and accompanying text.

71. 239 U.S. 441 (1915).

72. Id at 445.

73. Id at 446.

74. CAL. Gov't Code $\$ \S 65853-65857$ (West Supp. 1981).

75. 24 Cal. 3d 605, 596 P.2d 1134, 156 Cal. Rptr. 718 (1979).

76. Id at 613,596 P.2d at $1138,656 \mathrm{Cal}$ Rptr. at 722 .

77. Id at $615,596 \mathrm{P} .2 \mathrm{~d}$ at 1139, $156 \mathrm{Cal}$. Rptr. at 723. But cf. id at $620 \mathrm{n} .1,596 \mathrm{P} .2 \mathrm{~d}$ at 1142 
due process context, the court did not allude to any categorical rules that label a particular act as legislative or nonlegislative. Horn gives no indication that cases involving due process claims have followed the formalistic bent of the standard of review decisions. ${ }^{78}$ Indeed, as the court expressly stated, the teaching of Horn is that "[t]he general application of due process principles is flexible, depending on the nature of the competing interests involved." 79

Thus, the legislative-nonlegislative distinction was developed largely outside the context of the imitiative in California. As a inethod for determining the proper standard of judicial review, the distinction has been rigidly applied with little analysis. ${ }^{80}$ As a method for determining when notice and a hearing are required, however, the distinction has been inade in a far more flexible framework, as demonstrated by the Horn court's use of the Bi-Metallic standard. The analysis of cases involving initiatives has necessarily been based on eleinents of this disparate scheme of developinent.

\section{The Legislative-Nonlegislative Distinction and the Initiative}

Charter cities were unhampered by the line of cases denying the voters of general law cities the power to zone by imitiative. ${ }^{81}$ Cases dealing with zoning initiatives in charter cities, therefore, comprise the apphication of the legislative-nonlegislative distinction to the initiative. These cases indicate that courts have followed the inore flexible $B i-M e$ tallic approach. For example, cases which have allowed the use of direct legislation in zoning decisions have generally concerned changes which, if not comprehensive, at least affected all citizens alike. ${ }^{82}$ On

n.1, 156 Cal. Rptr. at 727 n.l (Newman, J., concurring) ('I wonder too why the exercise of judgment, and the careful balancing of conflicting interests, [are] the hallmark of the adjudicative process.' . . . Do they not mark also the work of conscientious legislators?').

78. See supra note 63 and accompanying text.

79. 24 Cal. $3 \mathrm{~d}$ at 617,596 P.2d at 1140,156 Cal. Rptr. at 724 .

80. California uses the "categorical" approach in the standard of review cases. See Comment, The Initiative and Referendum's Use in Zoning, 64 CALIF. L. REv. 74, 89 (1976).

81. See supra note 50.

82. See, e.g., Associated Homebuilders of the Greater Eastbay, Inc. v. City of Livermore, 18 Cal. 3d 582, 557 P.2d 473, 135 Cal. Rptr. 41 (1976) (initiative to prohibit issuance of further residential building permits until local service facilities complied with specified standards upheld); Builders Ass'n v. Superior Court, 13 Cal. 3d 225, 529 P.2d 582, 118 Cal. Rptr. 158 (1974) (freeze on zoning until certain conditions met upleeld); San Diego Bldg. Contractors' Ass'n v. City Council of San Diego, 13 Cal. 3d 205, 529 P.2d 570, 118 Cal. Rptr. 146 (1974) (30-foot leight restriction on all buildings to be erected along coastline held properly enacted by initiative); Bayless v. Limber, 26 Cal. App. 3d 463, 102 Cal. Rptr. 647 (2d Dist. 1976) (initiative to prohibit oil well drilling in residentially zoned arcas of the city upheld); Duran v. Cassidy, 28 Cal. App. 3d 574, 104 Cal. Rptr. 793 (5th Dist. 1972) (power to initiate legislation held properly exercised by initiative petition to proscribe ownership or operation of a golf course by the city); Fletcler v. Porter, 203 Cal. App. 2d 313, 21 Cal. Rptr. 452 (1st Dist. 1962) (initiative petition to freeze zoning held valid on the groumd that it did not violate due process principles because it did not change the use of 
the other hand, decisions disapproving direct legislation have tended to involve actions which cut deeply into a few individuals' rights while only incidentally affecting surrounding landowners. ${ }^{83}$

The two notable exceptions, Dwyer v. City Council of Berkeley ${ }^{84}$ and Johnston v. City of Claremont, ${ }^{85}$ both allowing referenda on decisions affecting fairly sinall parcels, should be viewed as aberrations. In Dwyer, the court clearly felt that it was dealing with a decision that affected all citizens alike. ${ }^{86}$ The spirit of Bi-Metallic was therefore followed, even if applied in a somewhat strained manner. In Johnston, the court based its holding on other grounds, simply stating in dictuin, without analysis, that an anendment to a legislative act is always itself legislative. ${ }^{87}$ It may be significant that these two cases were decided during the reign of Hurst and the compatibility challenge, which treated imitiatives and referenda as involving separate due process problems. Dwyer and Johnston may have been decided partly on the unspoken rationale that due process had already been ensured before the inatter was subjected to direct legislation. The felt absence of due process questions may well have contributed to the Dwyer and Johnston courts' departures froin the general scheme. ${ }^{88}$

Thus, in applying the legislative-nonlegislative distinction to zon-

land or adversely affect property holders); see also Fishman v. City of Palo Alto, 86 Cal. App. 3d 506, 150 Cal. Rptr. 326 (Ist Dist. 1978) ("Cases holding land use inodifications to be legislative acts subject to referenda involved substantial land use changes.") (citing Wheelright v. County of Marin, 2 Cal. 3d 448, 467 P.2d 537, 85 Cal. Rptr. 809 (1970) (location of access road held proper subject for referendum)); Hughes v. City of Lincoln, 232 Cal. App. 2d 741, 43 Cal. Rptr. 306 (3d Dist. 1965) (decision to fiuoridate water subjected to referendum); O'Loane v. O'Rourke, $231 \mathrm{Cal}$. App. 2d 774, 42 Cal. Rptr. 283 (2d Dist. 1965) (resolution to adopt general plan for city properly referred); Reagan v. City of Sausalito, 210 Cal. App. 2d 618, 26 Cal. Rptr. 775 (1st Dist. 1962) (resolution to acquire land for city park properly referred).

83. See, e.g., Simpson v. Hite, 36 Cal. 2d 125, 222 P.2d 225 (1950) (selection and designation of site for courtroom building held not properly subjected to direct legislation); Starbuck v. City of Fullerton, 34 Cal. App. 683, 168 P. 583 (2d Dist. 1917) (street improvement acts held not properly subjected to referendum); Chase v. Kalber, 28 Cal. App. 561, 153 P. 397 (3d Dist. 1915) (same).

84. 200 Cal. 505, 253 P. 932 (1927).

85. 49 Cal. 2d 826, 323 P.2d 71 (1958).

86. This is evident in the way the court distingnished the street improvement cases in which referenda had been disallowed, see supra note 83, saying, "[s]treet improvcinent laws must froin the nature of the results to be attained operate upon districts or fractional parts of cities, and it was not within the contemplation or intention of the framers of the law that they should be treated as general, comprehensive schemes. In none of the street improvement cases cited was the question of an amendinent affecting an ordinance that operated upon all portions of the inunicipality . . . touched upon." $200 \mathrm{Cal}$. at 518, 253 P. at 937.

87. $49 \mathrm{Cal} .2 \mathrm{~d}$ at 834,323 P.2d at 76 ; see supra note 63.

88. While initiatives and referenda share some characteristics, there are reasons for distinguishing the types of direct legislation on due process grounds. A referenduni takes place after due process has been had. Therefore, the danger of an individual's interest being erroneously curtailed may be less. See Kahn, In Accordance With a Constitutional Plan: Procedural Due Process and Zoning Decisions, 6 HASTINGS CoNST. L.Q. 1020, 1047-48 (1979). 
ing initiatives, California courts ${ }^{89}$ have favored the flexible Bi-Metallic approach over the nore rigid, formalistic one suggested in Johnston. As the San Diego court put it, legislative acts are those "establishing a broad, generally applicable rule of conduct on the basis of a general public policy."90 Inherent in this definition is the notion that courts must look to the substance of an act to see whether it indeed formulates a broad rule before determining if it is legislative. ${ }^{91}$ In fact, only once with regard to a referendum, ${ }^{92}$ and never where an initiative was concerned, has a California court declared a flat rule that the ainendinent of a zoning ordinance is invariably a legislative act. It was against this background that Arnel arose.

III

ANALYSIS

In Arnel, the California Suprene Court for the first time undertook to decide the propriety of using an initiative to rezone a single parcel of land. The inajority inisapplied the characterization analysis developed in earher California cases and thereby reached an indefensible result. This Section will trace the fallacies in the court's application of the legislative-nonlegislative distinction. It will then discuss the

89. In distinguishing legislative from nonlegislative acts, many other jurisdictions have resisted the rigid approach that California uses in the standard of review context. See supra notes 59-69 and accompanying text. These jurisdictions adopt a functional approach, asking whether the decision in question produces a general rule or policy applicable to an open class of individuals, interests, or situations, or whether it entails the application of general rules or policies to specific individuals, interests, or situations. The former are deemed legislative, and the latter nonlegislative, actions. See Wolfstone, supra note 57, at 87-88; Comment, Zoning Amendments-The Product of Judicial or Quasi-Judicial Action, 33 OHIo ST. L.J. 130, 131-32 (1972).

This functional approach was first applied in the standard of review context. See, e.g., Snyder v. City of Lakewood, 189 Colo. 421, 542 P.2d 371 (1975) (rezoning of a church property lield quasi-judicial and therefore subject to review); Fasano v. Board of County Comm'rs, 264 Or. 574, 507 P.2d 23 (1973) (amendment to county zoning act affecting 32 acres was quasi-judicial, thereby demanding a more rigorous judicial review than that accorded ordinary legislative acts); Marggi v. Ruecker, 20 Or. App. 669, 533 P.2d 1372 (1975) (trial court erred in characterizing rezoning of 5.29-acre plot as legislative and not subject to judicial review). It was extended to cases questioning the propriety of direct legislation in land use decisions. See, e.g., Fornan v. Eagle Thrifty Drugs, 89 Nev. 533, 516 P.2d 1234 (1973) (rezoning of single piece of property is administrative and not a proper subject for initiative). Courts using the functional approach recognize that while a zoning amendment may involve important questions of public policy, the decision lias far greater impact on oue group of citizens than on the public generally. See, e.g., Fleming v. City of Tacoma, 81 Wash. 2d 292, 299, 502 P.2d 327, 331 (1972) ("II]n amending a zoning code, or reclassifying land thereunder, the same body, im effect, makes an adjudicatiou between the rights sought by the proponents and those claimed by the opponents of the zoning change. The parties whose interests are affected are readily identifiable.").

90. 13 Cal. $3 \mathrm{~d}$ at 213,529 P.2d at 574, $118 \mathrm{Cal}$. Rptr. at 150.

91. See infra text accoinpanying notes 96-101.

92. Johnston v. City of Claremont, 49 Cal. 2d 826, 323 P.2d 71 (1958). Referendnun cases may have been perceived by the Johnston court as presenting different questions. See supra text accompanying note 87 . 
majority's failure to consider adequately the plaintiffs' due process claims. Finally, it suggests an alternative analysis to that employed by the court.

\section{A. The Majority's Misuse of the Characterization Approach}

In San Diego Building Contractors' Association v. City Council of San Diego,,$^{93}$ the California Supreme Court accepted the characterization analysis as the proper method for determining the propriety of an imitiative. In Arnel, it took the labels used in the characterization inethod too seriously by looking to the forn of the decision alone. It is true that the decision taken by the Costa Mesa voters assuined the shape of a zoning amendment and therefore appeared, in forn, to be legislative. ${ }^{94}$ But in characterizing a decision as legislative or nonlegislative, form should not be dispositive. Correct use of the characterization analysis requires courts to look through forn to substance. ${ }^{95}$ Since the premise of the analysis is that sone decisions are legislative and others are not, simply designating all zoning amendments as legislative renders the characterization approach singularly nonanalytical; it denigrates it to a mechamical leveling process whose function is superfluous.

No previous zoning initiative case in California has indicated that the characterization analysis should be applied so inechanically. The San Diego court, after approving Justice Holınes' language in Bi-Metallic, ${ }^{96}$ made it clear that decisions that constituted "legislation of the classic inold, establishing a broad, generally applicable rule of conduct on the basis of a general public policy"97 involved different constitutional considerations than decisions not so wide-ranging. Thus, San Diego required vigorous analysis of the substance of the ordinance. The inajority in San Diego did not siniply declare that zoning annendinents are always legislative, nor did it hint that forn was the dispositive factor in the analysis. ${ }^{98}$ Similarly, the court in Associated

93. 13 Cal. 3d 205, 529 P.2d 570, 118 Cal. Rptr. 146 (1974). For further discussion, see supra text accompanying note 54 .

94. See Glenn, supra note 44, at 295: "[A]n amendment is formally an act of legislation. Some courts have been unable or unwilling to look beyond this form to find an 'administrative' substance."

95. See id at 295; see also Comment, supra note 80, at 89 ("[A]n adjudicative-legislative distinction based entirely on the form of the local land-use action would lead to unrealistic judicial results"); Comment, Limitations on Initiative and Referendum, 3 STAN. L. REv. 497, 503 (1951).

96. See supra text accompanying notes 71-73.

97. $13 \mathrm{Cal}$. 3d at $213,529 \mathrm{P} .2 \mathrm{~d}$ at $574,118 \mathrm{Cal}$. Rptr. at 150.

98. Two elements of the court's opinion in San Diego made clear its reluctance to adopt the strict form-over-substance approach. First of all, the court steadfastly refused to rest upon the Johnston dictum that amendments to legislative acts are always legislative; in fact, it relegated consideration of Johnston to mere mention in a footnote. Id at 212 n.5, 529 P.2d at 574 n.5, 118 Cal. Rptr. at 150 n.5. Second, the court repeatedly stated that the ordimance in San Diego was an 
Homebuilders of the Greater Eastbay, Inc. v. City of Livermore ${ }^{99}$ resisted the temptation to follow blindly the maxim that ordinances and amendments thereto are always legislative. ${ }^{100}$ In fact, even before the characterization analysis was expressly adopted, courts took far more into consideration than form when deciding whether a particular act was legislative or nonlegislative. ${ }^{101}$

The Arnel court took too lightly its own recent pronouncements on the propriety of the initiative in land use decisions. Instead, the majority turned to the standard of review cases, which had developed a rigid line dividing legislative and nonlegislative acts. ${ }^{102}$ The court should not have attempted sinuply to transfer the rule used in the standard of review cases to a situation involving the initiative, because the consequences arising from use of the legislative-nonlegislative distinction in the two contexts are vastly different. ${ }^{103}$

First of all, in deciding proper standards of review for official acts, courts are merely adoptimg, as a preliminary matter, a framework for further analysis. Application of the legislative-nonlegislative distinction here does not carry with it the necessity of coinpletely invalidatimg the act. ${ }^{104}$ In the initiative context, on the other hand, applying the

exercise of general zoning legislation, implying there was some other, less wide-ranging kind of zoning legislation that its holding did not necessarily reach. See, e.g., id. at 205, 529 P.2d at 573, 118 Cal. Rptr. at 149 ("General zoning legislation may be enacted without affording affected landowners 'notice and hearing.' ") (emphasis added).

While San Diego stressed it was addressing only general zoning legislation, the Livermore court's view of San Diego was somewhat different: "[San Diego] held that a city violates no constitutional prohibition in enacting $a$ zoning ordinance without notice and hearing to landowners, and hence may do so by initiative." $18 \mathrm{Cal}$. 3d at 593, 557 P.2d at $479,135 \mathrm{Cal}$. Rptr. at 47 (einphasis added). This summary completely overlooks the "general zoning legislation" factor on which San Diego was based. It therefore made San Diego sound much more like a form-oversubstance decision that it really was. This mischaracterization may well have been a forewarning that courts were likely to misread San Diego, a theory certainly borne out in Amel.

99. 18 Cal. 3d 582, 557 P.2d 473, 135 Cal. Rptr. 41 (1976).

100. See Horn v. County of Ventura, 24 Cal. 3d 605, 596 P.2d 1134, 156 Cal. Rptr. 718 (1979). While this case did not involve an initiative, it followed the characterization analysis of San Diego, thus reaffirming that court's approach; it never, however, stated a rule that form should prevail in the determination.

101. See, e.g., Wheelright v. County of Marin, 2 Cal. 3d 448, 457-58, 467 P.2d 537, 543, 85 Cal. Rptr. 809, 815 (1970).

102. Sce supra notes $59-69$ and accompanying text.

103. Even the Amel majority admitted that the legislative-nonlegislative distinction is used in many different contexts. $28 \mathrm{Cal}$. 3d at 516, 620 P.2d at 568, 169 Cal. Rptr. at 907. The court, however, stopped there and failed to recognize that the distinction may mean different things in different contexts.

104. Thus, when a court reviews a nonlegislative act, it may still proceed either to uphold the act or invalidate it. Compare Jacobson v. County of Los Angeles, 69 Cal. App. 3d 374, $137 \mathrm{Cal}$. Rptr. 909 (2d Dist. 1977) (administrative grant of use permit upheld where findings were supported by substantial evidence) with Topanga Ass'n for a Scenic Community v. County of Los Angeles, 11 Cal. 3d 506, 522 P.2d 12, 113 Cal. Rptr. 836 (1974) (administrative grant of variance reversed where no written findings were issued by planning commission). Similarly, when a court 
distimction dictates the outcome of the case: if the initiative is legislative, it is valid; if it is nonlegislative, it must be struck down. ${ }^{105}$ Thus, the choice of labels takes on vastly different dimensions depending on its context: its effects are preliminary where the standard of review is at issue, but conclusory on the merits where a zoning initiative is challenged. The result is that the Arnel court is deinanding far inore mileage from the distinction than it was ever intended to deliver.

Furthermore, when the courts merely determine the proper standard of review for a particular case, their determination, in and of itself, deprives no one of procedural due process. For example, a finding that a particular zoning amendment is a legislative act reviewable by ordimary mandanus ${ }^{106}$ still reserves to the property owner the procedural requirements of the state zoning law. ${ }^{107}$ Similarly, a finding that the grant of a variance is a nonlegislative act does not deny the permitseeker written findings in support of the administrative decision. ${ }^{108}$ In neither case does the application of the legislative or nonlegislative tag carry with it the conclusion that soineone has been unconstitutionally deprived of a procedural right. Where the use of the initiative is challenged, however, one consequence of the characterization may be that a minority of voters is unable to defend its rights before they are taken away or curtailed by the majority. ${ }^{109}$ The issue of whether direct legislation will be tolerated in such a case should not be elided by applying a strictly formalistic rule. ${ }^{110}$

In sum, the legislative-nonlegislative distinction was developed to

reviews a legislative act, the act might still be either upheld or struck down. Compare Ensign Bickford Realty Corp. v. City Council, 68 Cal. App. 3d 467, 137 Cal. Rptr. 304 (1st Dist. 1977) (legislative determination refusing to rezone residential parcel for a shopping center upheld where supported by reasonable facts) with Arnel Dev. Co. v. City of Costa Mcsa, 126 Cal. App. 3d 330, $178 \mathrm{Cal}$. Rptr. 723 (4th Dist. 1981) (on remand to court of appeal, legislative act of rezoning particular parcel held arbitrary and capricious, hence invalid). See also supra note 13. A resort to labels does not conclusively determine the outcome of the appeal in cither lcgislative or nonlegislative cases.

105. More precisely, the process of the initiative is valid or invalid depending on its characterization. However, the content of the initiative inay demand further consideration. See the discussion of Arnel II, supra note 13.

106. See supra note 61.

107. CAL. Gov'T CoDE $\S \S 65853-65857$ (West Supp. 1982).

108. See Topanga Ass'n for a Scemic Community v. County of Los Angeles, 11 Cal. 3d 506, 522 P.2d 12, 113 Cal. Rptr. 836 (1974).

109. It is of course possible that the initiative procedure can be adapted to ensure notice and a hearing if a few individuals are to be affected by a given decision. This would eliminate the due process objection to the initiative. See San Diego Bldg. Contractors' Ass'n v. Superior Court, 13 Cal. 3d 205, 223-24, 529 P.2d 570, 582, 118 Cal. Rptr. 146, 158 (1974) (Burke, J., dissenting).

110. See City of Eastlake v. Forest City Enters., Inc., 426 U.S. 668, 686 (1976) (Stevens, J., dissenting): "When we examine a state procedure for the purpose of deciding whether it comports with the constitutional standard of due process, the fact that a State may give it a 'legislative' label should not save an otherwise invalid procedure." 
facilitate preliminary decisions regarding the proper standard of review. By simply transferring the characterization approach to the initiative context, the Arnel court improperly turned a preliminary analytical tool into a device powerful enough to dispose of entire cases on their merits. ${ }^{111}$ The court failed to consider that separating legislative from nonlegislative acts involves various factors, depending upon the consequences of the distinction. ${ }^{112}$ In sum, by focusing on form and disregarding substance, the court misapplied the cliaracterization analysis developed in its prior zoning initiative cases. ${ }^{113}$

\section{B. The Majority's Inadequate Handling of the Due Process Issue}

Both the Califorma and the federal constitutions guarantee that the government shall deprive no one of property without due process of law. ${ }^{114}$ The formulation of this constitutional command invites further inquiry: what is the scope of a protected interest in "property"? What exactly constitutes "due process"? While the answers are by no ineans clear, proper analysis of a challenge to state action based on the due process clauses requires a court to resolve the questions in a way that ensures fairness to all litigants, for fairness is the essence of due

111. Cautioning that "[l]abels attached in one legal context are likely to be used in other contexts without independent analysis", Professor Glenn admonished that the legislative-administrative judgment should be based on independent consideration of the factors involved in each case. Glenn, supra note 44, at 302.

112. Justice Richardson properly separated the contexts in his dissent: "I emphasize that in the present case we are concerned with the legislative or adjudicative character of the ordinance for the purpose of determining whether due process requirements were satisfed. We are not presented with the question whether the adjudicative nature of rezoning ordinances of this kind requires either a more probing form of judicial review or the preparation of judicial-type findings." $28 \mathrm{Cal}$. 3d at 531, 620 P.2d at 577, 169 Cal. Rptr. at 916 (Richardson, J., dissenting) (emphasis in original).

113. See supra note 98 and accompanying text. By its mechanical application of the clraracterization analysis, the court overlooked the virtual unanimity anrong modern commentators that the rezoning of a single parcel slould be deemed a nonlegislative act, outside the scope of initiative and subject to due process requirements. See, e.g., Booth, A Realistic Reexamination of Rezoning Procedure: The Complementary Requirements of Due Pracess and Judicial Review, $10 \mathrm{GA} . \mathrm{L}$. REv. 753, 772 (1976) (the unique effect of a rezoning decision on the individual and its basis in demonstrable facts peculiar to the particular application make it a decision which is an exercise of judgment primarily judicial in claracter, not legislative); Freilich, Fasano v. Board of County Comm'rs of Washington Connty: Is Rezoning an Administrative or Legislative Function? 6 URB. LAW. vii (1974); Glenn, supra note 44, at 304-05 (small parcel rezoning not a traditional legislative judgment as it imposes regulations in the context of a particular developinent proposal and hence is not the kind of governance ineant for enactment by direct legislation); Comment, Zoning by Initiative in California: A Critical Analysis, 12 LoyolA L.A.L. Rev. 903, 925-26 (1979) (if the legislative-adjudicative distinction must be used, zoning amendments slould be seen as adjudicative); Comment, Zoning Amendments-The Product of Judicial or Quasi-Judicial Action, 33 OHro ST. L.J. 130, 137 (1972) (zoning anendment is quasi-judicial if a specific tract of land is involved since it does not constitute the formulation of a general rule or policy).

114. U.S. Const. amends. V, XIV; CAL. Const. art. I, § 7(a). 
process. $^{115}$

The Arnel majority's consideration of the plaintiffs' claims that the use of the initiative violated notions of fairness and unconstitutionally deprived them of their property rights was faulty in two ways. First, the majority cited unpersuasive precedent in dismissing Arnel's claims that both its federal and state due process guarantees had been violated. Second, by mechanically applying the proposition that the amendment to a legislative act inust itself be legislative, the Arnel majority avoided assessing the nature of Arnel's interest and the steps required by the federal and state constitutions; indeed, the court seemed to lose sight of the goal of fairness. This Section addresses the first concern; the next section will discuss the proper due process analysis, which the majority avoided by adherence to an overly rigid rule.

\section{The Federal Due Process Claim}

The plaintiffs claimed that use of the initiative process to rezone their property violated the fourteenth amendment's guarantee of due process because it afforded thein neither notice nor the opportunity to be heard before their use of the property was curtailed. The inajority dismissed this claim, concluding that "classification of the rezoning ordimance as a legislative act, thus permitting its enactment by imitiative, does not violate the federal Constitution."116 The court relied for this conclusion on the United States Supreme Court's decision in City of Eastlake v. Forest City Enterprises, Inc. ${ }^{117}$ Eastlake involved an Ohio city's charter amendment requiring all land use decisions made by the city council to be subjected to inandatory referenda for voter approval. The Supreme Court of Ohio had found the charter amendment invalid as a standardless delegation of legislative power to the people violating the due process clause of the fourteenth amendment. ${ }^{118} \mathrm{~A}$ majority of the Supreme Court, speaking through Chief Justice Burger, reversed, holding that the mandatory referendun provision did not in itself violate the federal Constitution's due process guarantee. ${ }^{119}$

Eastlake is distinguishable and does not sanction the Arnel result. ${ }^{120}$ The basis of the Ohio Supreme Court's decision was that the

115. Galvan v. Press, 347 U.S. 522 (1954).

116. 28 Cal. 3d at 521, 620 P.2d at 571, 169 Cal. Rptr. at 910.

117. 426 U.S. 668 (1976).

118. 41 Ohio St. 2d 187, 196, 324 N.E.2d 740, 746 (1975). See also Wolfstone, supra note 57, at $90-92$.

119. 426 U.S. at 672.

120. See Glenn, supra note 44, at 268-69 n.16: "If an initiative imposed zoning restrictions on a specific parcel of land smaller than San Diego's coastal zone . . . the United States Supreme Court might well hold that such an initiative would violate the due process rights of the affected landowner." 
delegation to the voters included no standards to guide their choices, and that the resulting potential for arbitrariness in the electorate's decision violated the federal due process guarantee. The focus, then, was clearly on the standardless delegation. ${ }^{121}$ In reversing, the Supreme Court found no constitutionally offensive standardless delegation because it found no delegation: the right of referendun was reserved in the people of Ohio and therefore talk of delegation to thein was inappropriate. ${ }^{122}$ The Court shared the Ohio Supreine Court's concern about the substantive results of a zoning decision made by the people, but felt that " $[t]$ he critical constitutional inquiry . . . is whether the zoning restriction produces arbitrary or capricious results." 123 Thus, while the Ohio court felt the quality of the decisioninaking process was critical in resolving the due process claims, the Supreine Court was concerned with the quality of the result alone. ${ }^{124}$

Eastlake shows that not all due process problems are alike: the Arnel issue simply was not prominent there. Eastlake did not involve the fairness of enacting a zoning change without allowing the affected property owner notice and the opportunity to be heard. ${ }^{125}$ The only issue on appeal was whether the Ohio Supreme Court correctly held that the potential for arbitrary decisioninaking violated the due process clause. ${ }^{126}$ In the context of Arnel, the only rule that can be derived from Eastlake is that, where land use decisions are involved, an initiative, like a referendun, does not in itself constitute a standardless delegation of power to the voters violative of due process. ${ }^{127}$ This,

121. 41 Ohio St. 2d 187, 195, 324 N.E.2d 740, 746 (1975) ("A reasonable use of property, made possible by appropriate legislative action, may not be made dependent upon the potentially arbitrary and unreasonable whims of the voting public.").

122. 426 U.S. at $672-73$; see also Wolfstone, supra note 57 , at 92-93.

123. 426 U.S. at $676 \mathrm{n} .10$ (emphasis added).

124. Arnel, too, shared the Eastlake concern for quality of the result because it left open for further review the substance of the initiative. $28 \mathrm{Cal}$. 3d at 521, 620 P.2d at 571, $169 \mathrm{Cal}$. Rptr. at 910. On retransfer to the court of appeal, the initiative was invalidated on these grounds. See supra note 13.

125. Justice Powell did bring up this question in his cryptic, one-paragraph dissent, 426 U.S. at 680 (Powell, J., dissenting), but it seems to have been ignored by the majority. In the years just prior to Eastlake, the Court had decided no small number of procedural due process cases in which the right to a hearing was at issue. See, e.g., North Georgia Finishing, Inc. v. Di-Cliem, Inc., 419 U.S. 601 (1975); Goss v. Lopez, 419 U.S. 565 (1975); Mitchell v. W.T. Grant Co., 416 U.S. 600 (1974); Board of Regents v. Roth, 408 U.S. 564 (1972); Bell v. Burson, 402 U.S. 535 (1971); Sniadach v. Family Fin. Corp., 395 U.S. 337 (1969). The failure of the majority to cite even one of these precedents makes clear that it did not view Eastlake as merely another notice and hearing case.

126. 426 U.S. at $677 \mathrm{n} .11$. The case was remanded to the state court for further proceedings; any notice and hearing issues presumably could have been brought up then.

127. In an attempt to broaden the rule of Eastlake, the Arnel majority claimed that Justice Stevens' dissent had argued that due process required a hearing for the rezoning of small parcels of property, and that this contention had been forcefully rejected by the majority. In fact, Justice Stevens' dissent advanced no such argument. Rather, Stevens agreed with the Ohio Supreme 
however, was not a question in Arnel.

Eastlake, therefore, does not provide a basis for rejecting the Arnel plaintiffs' claims that use of the initiative to rezone their property precluded notice and hearing and thus violated the fourteenth amendment's guarantee of due process. That the California court relied on Eastlake to support its resolution of issues never addressed by the United States Supreme Court reduces Eastlake's applicability to the vanishing point. In passing on the federal due process claims, then, the Arnel majority should have looked beyond Eastlake to other Supreme Court pronouncements on procedural due process. ${ }^{128}$

\section{The State Due Process Claim}

The Arnel majority turned to the decision in San Diego to refute the contention that the state constitution prohibited the use of the initiative in this instance. In doing so, it ignored the differences between the change made by initiative in San Diego and that effected by the Costa Mesa initiative. As discussed above, San Diego stands only for the proposition that zoning changes of a general and wide-ranging nature may be accomplished by initiative because the lack of notice and hearing to those affected by a far-reaching change does not violate the constitution. ${ }^{129}$ The Arnel court's sinuplistic conclusion that San Diego

Court; his objection to the referendum provision was not that it provided for no hearing, but that the people in deciding had to obey no articulable or reviewable rules. Id. at 694 (Stcvens, J., dissenting).

Since the Arnel inajority misconstrued Stevens' dissent, it also erred as to what the Eastlake majority was rejecting when it rejected " $t$ t]he fears expressed in dissent . . . that the procedure at issue here is 'fundamentally unfair' to landowners . . . ." Id. at 679 n.13. This statement is itself confusing, since there were two dissenting opinions, both of which clained that fundanental unfairness resulted from the referendum procedure. The dissents were based on different grounds: Justice Powell briefiy argued that the lack of a hearing in the referendum procedure made it unconstitutional, while Justice Stevens, joined by Justice Brennan, thought that the lack of standards was fatal. It is not clear whether the inajority mcant to attack one or both of the dissents in its footnote. The Burger opinion attempted to allay fears of unfairness with a reminder that administrative rehef may be sought to counter any hardships caused by a zoning decision. Justice Stevens articulated the fallacy of the majority's solution in a footnote of his own: "There is no claim that the city's zoning plan is arbitrary or nnconstitutional . . . . But, if there is a constitutional right to fundamental fairness in the procedure applicable to an ordinary request for an amendinent to the zoning . . . [of] an individual parcel, that right is not vindicated by the opportunity to make a substantive due process attack on the ordinance itself." Id. at 695 n.16 (Stevens, J., dissenting).

The only conclusion that may be drawn is that it is sinuply nnclear whether the majority in fact rejected Powell's position on a hearing. See Kahn, supra note 88, at 1047. In any case, all of this renders the California Supreme Court's reliance on the Eastlake inajority's footnote as solid as quicksand. Though Powell's dissent inerely noted the lack of a hearing, it is clear that neither the majority nor the primary Eastlake dissenters considered it a notice and hearing case. See supra note 125.

128. See supra cases cited in note 125. For further discussion on the proper due process analysis, see infra notes $130-55$ and accompanying text.

129. See supra note 98 and accompanying text. 
mandates no due process guarantees whenever zoning by initiative is at issue is unpersuasive.

\section{A Balancing Approach to Zoning by Initiative}

The Arnel majority avoided facing the essential question of fairness, which is the gravamen of due process claims, ${ }^{130}$ since it attempted to answer such claims by placing in their path the insurmountable barrier of the "legislative" label. This approach iniplies that a property owner's due process rights derive from the classification of an act as legislative or nonlegislative. In fact, due process rights are far too fundamental to be determined solely by a process of labeling. In basing its decision on the legislative-nonlegislative distinction, Arnel employed an analysis that is inconsistent with the United States Supreme Court's pronounceinents on the correct method of adjudicating those clainis. The Court has used a balancing approach: whether the Constitution inandates due process in a given situation depends upon (1) a showing that a protected interest has been abridged by state action; and (2) the result of balancing the size of the protected imterest agamst the administrative costs involved in providing procedural safeguards. ${ }^{131}$ The fact that the characterization analysis is antithetical to this balancing approach may render it constitutionally defective instead of merely analytically weak. ${ }^{132}$ The Arnel court was therefore wrong to limit itself to the characterization analysis; rather, it should have incorporated a balancing test to deal with the due process issue.

Use of such a balancing process to evaluate the plaintiffs' due process claims in Arnel would also have been consistent with the Califormia Supreme Court's most recent discussions of due process. The court has held that identification of the dictates of due process requires consideration of the private imterest that will be affected by the official action, the risk of erroneous deprivation of that interest through the procedures used, and the government's interest, including the function mvolved and the fiscal and administrative burdens that the additional

130. See supra note 115 and accompanying text.

131. Board of Regents v. Roth, 408 U.S. 564 (1972).

132. See Kahn, supra note 88, at 1035 .

The balancing test and the characterization test differ radically in their operation. Use of the characterization test sets up a threshold. An official decision must cross the line between legislative and nonlegislative acts before use of direct legislation will be barred and rights to due process recognized. Operation of this test is harshest when an act barely crosses the threshold-i.e., it affects just enough people or property to be deemed legislative- because those affected are therefore wholly demied procedural protection. The balancing approach works far more flexibly. The only threshold requirement is that a protected interest be shown. If it is, the protected interest factor has soine theoretical weight greater than zero; hence, the governmental interest side of the equation must be weighed also so that it may be balanced against the private interest. See infra notes 137-55 and accompanying text. 
procedural requirements would entail. ${ }^{133}$ Moreover, the California Supreme Court has expressly applied this flexible analysis to land use decisions. In Horn v. County of Ventura,$^{134}$ the court's most recent pronouncement on due process in zoning decisions, the inajority recognized the validity of the due process balancing test: it ascertained that the plaintiff had shown a sufficiently substantial deprivation of property $^{135}$ and then, in deciding that he was entitled to notice and the opportunity to be heard, stated, "[T]he general apphication of due process principles is flexible, depending on the nature of the competing interests involved." 136

The next Section undertakes an analysis of how the balancing approach would have worked in Arnel. First, it discusses the law on what constitutes a protected interest. Next, it identifles and analyzes the governmental interests at stake. Finally, the proposed balancing approach is applied to the facts in Arnel, suggesting a different result than that reached by the California Supreme Court.

\section{Measuring the Protected Interest}

For a balancing approach to apply, a landowner must first be able to reach the scales by showing impairment of an interest encompassed by the fourteenth amendment's protection of property. ${ }^{137}$ The seminal Supreme Court decision discussing such property interests is Board of Regents $v$. Roth, ${ }^{138}$ where the Court noted:

Property interests, of course, are not created by the Constitution.

Rather, they are created and their dimensions are defined by existing rules or understandings that stem from an independent source such as state law-rules or understandings that secure certaim benefits and that support claims of entitlement to those benefits. ${ }^{139}$

Finding such state law understandings in the context of land use decisions appears relatively simple, since it has seldom been questioned that landowners have due process rights where contemplated administrative action would curtail profitable use of their lands. ${ }^{140}$ In Califor-

133. Van Atta v. Scott, 27 Cal. 3d 424, 434, 613 P.2d 210, 214, 166 Cal. Rptr. 149, 153 (1980); see also People v. Ramirez, 25 Cal. 3d 260, 269, 599 P.2d 622, 627-28, 158 Cal. Rptr. 316, 321 (1979).

134. 24 Cal. 3d 605, 596 P.2d 1134, 156 Cal. Rptr. 718 (1979).

135. Id. at 615,596 P.2d at 1139,156 Cal. Rptr. at 723 .

136. Id. at 617,596 P.2d at 1140,156 Cal. Rptr. at 724 .

137. Morrissey v. Brewer, 408 U.S. 471, 481 (1972).

138. 408 U.S. 564 (1972).

139. Id. at 577.

140. As Professor Tribe has put it, " $t$ t]he Supreme Court has . . . consistently recognized that due process requirements are implicated whenever the enforcement power of government is employed to deprive an individual of an interest, derived from the common law, in peaceful possession or use of real . . property." L. TRIBe, American Constitutional Law 509 (1978) (footnotes omitted). Justice Story made an even more sweeping assertion: the "terms 'life,' 'lib- 
nia, state law clearly gives property owners the right to a hearing before zoning amendments affecting their property may be approved. ${ }^{141}$ Zoning laws therefore secure certain benefits to landowners-for example, the right to build an apartment building - and support claims of entitlement to those benefits by forbidding a change without a hearing. Thus, zoning classifications fit in neatly with the Roth analysis; they are property interests worthy of protection.

Arguably, however, some substantive rules of California land use law indicate that Arnel had no protected interest abridged by a change in the zoning classification of its property. For example, the landowner in HFH, Ltd. v. Superior Court ${ }^{142}$ sought damages in inverse condemnation for the downzoning of his property from commercial to singlefamily residential. Denying the remedy, the court quoted from an earher appellate decision: "[L]andowners have no vested right in existing or anticipated zoning ordinances."143 This rule, however, is distinguishable from the due process issue because the right to be heard is entirely separate frons the right to prevail. ${ }^{144} H F H$ and its progeny ${ }^{145}$ establish only that property owners have no compensable interest in a zoning classification. The cases clearly do not invalidate landowners' rights, included in their ownership of land, to a hearing before any action affecting their interest is taken. If they did, the state zoning law requiring hearings prior to zoning annendinents would be constitutionally unnecessary. ${ }^{146}$ Thus, this line of seemingly damning California cases only delimits landowners' ability successfully to claim coinpensation for adverse zoning decisions. It does not bear on their right to due

erty' and 'property' . . . a are representative terms, and are intended and must be understood to cover every right to which a member of the body politic is entitled under the law." 2 J. STORY, Commentaries on the Constitution of the United States 697 (M. Bigelow 5th ed. 1891). And the Supreme Court has stated that "any legitimate use is properly within the protection of the Constitution." Washington ex rel. Seattle Title Trust Co. v. Roberge, 273 U.S. 116, 121 (1928).

141. See CAL. Gov'T CODE $\S \S 65853-65857$ (West Supp. 1982).

142. 15 Cal. 3d 508, 542 P.2d 237, 125 Cal. Rptr. 365 (1975).

143. Id. at 516,542 P.2d at 242,125 Cal. Rptr. at 370 .

144. "Including particular activities within the coustitutional definition of 'property' . . . always implies constitutional recognition of a procedural right to be heard even when a concededly valid government rule infringing that interest is enforced." L. TRIBE, supra note 140, at 511 (footnotes omitted); see also City of Eastlake v. Forest City Enters., 426 U.S. 668, 682 (1976) (Stevens, J., dissenting): "The fact that an individual owner . . may not have a legal right to the relief lie seeks does not mean he has no right to fair procedure in the consideration of the merits of his application."

145. See, e.g., Agins v. City of Tiburon, 24 Cal. 3d 266, 598 P.2d 25, 157 Cal. Rptr. 372 (1979), affd, 447 U.S. 255 (1980); Viso v. State, 92 Cal. App. 3d 15, 154 Cal. Rptr. 580 (3d Dist. 1979).

146. $H F H$ and Agins are more properly viewed as cases involving the question, "Was there a taking?", rather than, "Was there a property interest?" Agins conceded the latter point by describing the property interests as "constitutionally protected." $24 \mathrm{Cal} .3 \mathrm{~d}$ at 278, $598 \mathrm{P} .2 \mathrm{~d}$ at 32, $157 \mathrm{Cal}$. Rptr. at 379 (emphasis added); see also id. at 273, 598 P.2d at 28, 157 Cal. Rptr. at 375: "[Under the state and federal constitutions] [t]here is a clear, direct and unquestionable constitutional basis for the protection of private property. . . . 'Property,' in a legal seuse, has been broadly defined." 
process. ${ }^{147}$

Landowners facing a zoning change can therefore show a protected interest for purposes of procedural due process. The next step in the balancing process is to determine the size of any given owner's interest in order to balance it against governmental interests and administrative costs. What factors contribute to the strength of a landowner's right to due process? As always in the due process context, fairness is the goal. The conventional wisdoin is reminiscent of the Bi-Metallic test: due process rights must be recognized when an act specially affects only a few owners; the larger the affected group, the less compelling the individual's claim. ${ }^{148}$ Thus, the uniqueness of the claim is one important factor in assessing its weight. ${ }^{149}$

The size of the parcel affected by a land use decision may also contribute to the strength of its owner's claim. The theory here is that the smaller the parcel involved, the more likely it is that the course of action taken will depend more upon the facts of the individual case and correspondingly less upon any pohcy determination. ${ }^{150}$ Since a decision regarding a sinaller parcel involves a full adjudication of the rights of the parties interested in that parcel, a more accurate result is likely where the parties to be affected are heard. Accuracy in adjudication is part of the fairness that the due process clauses ensure. ${ }^{151}$ The constitu-

147. Another California rule dictates that unless a builder has obtained a building pernit, there is no vested right in any zoning classification that permits completion of a project following a rezoning of the parcel. See Avco Community Developers, Inc. v. South Coast Regional Comm'n, 17 Cal. 3d 785, 553 P.2d 546, 132 Cal. Rptr. 386 (1976). Again, this rule severely limits the landowner's ability to build in spite of a proposed zoning change, but it does not affect the procedural due process entitlement-notice and a hearing must still precede the zoning change. The rule merely reinforces the validity of Justice Stevens' statement that the right to relief is separate from the right to process. See supra note 144.

148. See supra notes 71-73 and accompanying text. Initially, this proposition may appear counterintuitive, simce it means that the government may damage a large group of persons without first affording notice and hearing but may not similarly damage one or several individuals absent some process. Paradoxically, in other words, to escape due process constrictions, government need only be certain it is curtailing the rights of a sufficiently large number of its citizens. There is, however, reason behind the rule. A large group of danaged individuals may express its displeasure with action taken at the polls; the affected individual has no such political power. For example, the general zoning ordinance at issue in San Diego which placed a height limitation on all buildings erected on the coastline, affected inany landowners similarly. See supra notes 54-55, 93 101 and accompanying text. Their displeasure therefore carried more pohitical clout than could the small group of three landowners adversely affected by the ainendment in Arnel. As Professor Tribe explains, "[T] he case for due process protection grows stronger as the identity of the persons affected by a governmental choice becomes clearer . . . ." L. TRIBE, supra note 140, at 503.

149. See Booth, supra note 113, at 776: "Fairness requires greater procedural protection when the action directly affects only a few individuals."

150. For example, the voters in San Diego, who decided that no tall buildings should be built anywhere on the coastline, made more of a broad policy determination than did the voters in Arnel, who merely dictated that no apartments should be built on one particular parcel.

151. See Kahn, supra note 88 , at 1024. 
tional mandate of procedural protection, therefore, becomes stronger as the value of process, as measured by its contribution to accuracy, grows-that is, as the decisions to be inade depend inore upon individual facts.

Two factors, then, have been identified as affecting the weight of a landowner's interest. First, the individual entitlement to due process becomes stronger as the number of landowners damaged by an official action dwindles. Second, the due process interest is likewise strengthened as the amount of land affected becomes sinaller. Thus, the size of an individual's protected interest is inversely related to the number of persons with whom a similar plight is shared and the scope of the official act.

\section{Measuring the Government's Interest}

In any given case, the protected private interest will be weighed agamst the administrative cost of providing due process. Generally, courts have held that some form of notice and hearing comprise the minimum due process requirement. ${ }^{152}$ How inuch will it cost the government to provide and administer such requirements? Agam, the question seems to come down to the number of persons affected. Where that number is small, the cost to government of providing them some notice of a proposed change and an opportumity to contest it is correspondingly minimal. As the affected group grows, so do administrative costs.

The state zoning law provides a good model for determining who should be entitled to notice of a proposed zoning change. Besides notice to the landowners, the statute mandates that notice be given to owners of all properties within 300 feet of the property subject to the change. ${ }^{153}$ Obviously, some zoning changes may affect inany members of the commumity other than those who own land close to the parcel in question. The imterests of such nonadjacent landowners, however, will be protected in a substantive review of the ordinance, for courts determining whether a zoning ordinance reasonably relates to the public welfare must consider the welfare of the entire region. ${ }^{154}$ Thus, the task

152. Mullane v. Central Hanover Bank and Trust Co., 339 U.S. 306, 313 (1949).

153. See CAL. Gov'T CODE $\$ \S 65854,65854.5$ (West Supp. 1982). If, however, there are more than 1,000 landowners within the 300 -foot zone, the mailing requirement may be replaced by a general advertisement. See id. $\$ 65854.5$ (b). In addition, landowners who are interested in but not located near the subject parcel may file a request for notice of proposed zoning changes and also receive mailed notice. See id. \& 65854(c).

154. See Associated Home Builders of the Greater Eastbay, Inc. v. City of Livermore, $18 \mathrm{Cal}$. 3d 582, 607, 557 P.2d 473, 487, 135 Cal. Rptr. 41, 55 (1976); Arnel Dev. Co. v. City of Costa Mesa, 126 Cal. App. 3d 330, 337-40, 178 Cal. Rptr. 723, 728-29 (4th Dist. 1981); see also Scott v. City of Indian Wells, 6 Cal. 3d 541, 492 P.2d 1137, 99 Cal. Rptr. 745 (1972) (holding that city must give 
of determining who is "affected by" a zoning change for procedural due process purposes is not difficult; courts addressing this issue need not involve themselves in the regional welfare quagmire, because the statute suggests a definition of who is entitled to notice of a proposed change.

Once it becomes clear who will be affected by a given zoning decision, projected government outlays for notice and hearing can be measured by estimating the costs of mailings, publication, advertising, and providing a fornm for a hearing. At one extreme, if the group to be affected is large, providing notice and hearing to all would be botll prohibitively expensive and unnecessary, smce such a large group should hold considerable political power. ${ }^{155}$ At the opposite pole, if the contemplated act would affect only one or two persons, administrative costs would be negligible and procedural safeguards essential. In the majority of cases, the answer is less obvious; cost to the government sliould be carefully weighed agamst the individual's interest, as discussed above.

Courts applying the balancing approach have integrated procedural fairness with considerations of administrative efficiency, and have accordingly found constitutional requirements of notice and hearing in the enactment of what would surely be labelled legislative acts ${ }^{156}$ if a cliaracterization test were used.

\section{The Balancing Test Applied}

Application of the balancing test to specific fact patterns deinonstrates that it provides more accurate and fair results than does a cliaracterization analysis applied solely witl regard to forn. For example,

notice and opportunity to be heard to adjacent landowners when a variance is considered, even when such landowners do not reside within the municipal border).

155. This is not to say that providing notice to a large group of affected persons would necessarily be expensive-less than mdividual notice would be possible. Since, however, the notice required in an administrative hearing is personal notice, a consideration of alternative forms of notice is not necessary here.

156. Caramico v. Secretary of Hous. and Urb. Dev., 509 F.2d 694 (2d Cir. 1974) (nonowner occupants of dwellings whose FHA-insured mortgages were being foreclosed, while having no right to federal assistance for relocation, did have a due process right to participate in the FHA decisionmaking process); Geneva Towers Tenants Org. v. Federated Mortgage Investors, 504 F.2d 483 (9th Cir. 1974) (tenants of two federally financed housing projects had due process right to notice and hearing before enactment of rent imcrease); Burr v. New Rochelle Mun. Hous. Auth., 479 F.2d 1165 (2d Cir. 1973) (due process required that a mumicipal housing authority accord notice and hearing to tenants before promulgating across-the-board rent increase); Argo v. Hills, 425 F. Supp. 151 (E.D.N.Y. 1977) (tenants had due process rights to notice and hearing before rents were imcreased by HUD, the guarantor of project mortgage); 515 Assocs. v. City of Newark, 424 F. Supp. 984 (D.N.J. 1977) (same); Powelton Civic Home Owners Ass'n v. Department of Hous. and Urb. Dev., 284 F. Supp. 809 (E.D. Pa. 1968) (residents of area affected by proposed urban renewal project, even though not alleging economic mjury or specific, individual legal rights, entitled to notice and hearing regarding the proposal). 
the situation in San Diego Building Contractors' Association v. City Council of San Diego and that in Arnel were treated similarly by the California Supreme Court: both the San Diego and the Costa Mesa ordinances were considered legislative, and the landowners affected by them were all deemed to have no entitlement to due process prior to the enactment of the law. In fact, however, the two ordinances and their effects were strikingly dissimilar. Only three landowners were affected by the Costa Mesa ordinance, and the parcel rezoned was very small. The brunt of the initiative's inipact fell onto Arnel; ${ }^{157}$ in effect, Arnel was required to confer a benefit upon Costa Mesa and to shoulder the cost of doing so. The San Diego ordinance, on the other hand, affected everyone who either owned or would in the future purchase land on the San Diego coastline. No particular landowner had to absorb the potential loss caused by passage of the new building prohibition. Thus, while the San Diego initiative was indeed legislative in nature, a closer look at the Costa Mesa initiative reveals that, despite its "legislative" label under the characterization inethod, it was actually adjudicative.

When the balancing test is applied, it is clear that different results should obtain in the two cases, and that any analysis rendering them similar must be erroneous. In a determination of whether due process was required in San Diego, one landowner's interest would be considered in light of the large number of other current or prospective owners who would be similarly affected by the ordinance and the large area the building prohibition covered. Weighed against the individual landowner's stake would be the governmental costs of providing notice and hearnig to all affected landowners. Given the large number of landowners potentially restricted by the prohibition, the inipossibility of ascertaining their identities, and the large size of the area affected, costs to the government would be fairly higl. Application of the balancing test in this instance indicates that the government's interest should prevail; any one landowner's plight is not so unique that some process is clearly mandated, and the costs of informing the whole group might be substantial. Thus, under the balancing test, the right result was obtained in San Diego.

The Arnel scenario was quite different. Arnel was one of only three parties affected by the Costa Mesa ordinance. His clain 1 of entitlement to process was made strong by the uniqueness of his plight; the effect of the ordinance, as the previous section slowed, was to burden Arnel for the perceived benefit of the majority. At the same time, the governmental costs of providing Arnel with notice and a liearing would have been minimal. The incidence of the new zoning was immediately

157. Arnel owned 50 of the 67.6 acres rezoned by the initiative. See supra note 7 and accompanying text. 
ascertainable, and notice could have been provided at little expense. The great disparity between their respective fact situations indicates that Arnel and San Diego should not have been similarly decided.

The balancing approach avoids the false equalization of interests in San Diego and Arnel that should be viewed as different from a due process standpoint. It refrains from forcing official actions into legislative or nonlegislative categories, and similarly shuns classifying individual interests as worthy or unworthy of protective procedures based on the type of act that abridges them. Instead, it measures official acts and private interests on a sliding scale. Balancing interests facilitates accurate and fair results; simply characterizing them is a step away from the goal of equity.

\section{CONCLUSION}

Proper resolution of the issues in Arnel deinanded a compromise between the people's reserved right to initiate legislation and the constitutionally protected rights of the affected landowners. Largely due to the precedent relied upon, and the analysis employed, the decision in Arnel does not reach that goal. By applying the characterization analysis it had adopted in San Diego, the California Supreme Court demonstrated the deficiencies inherent in that analysis. The inajority adhered incorrectly to a line of reasoning in which forn is dispositive, and did not adequately assess the due process contentions of the plaintiffs.

The Arnel decision is evidence that unfair results can stein from applying the characterization analysis to the rezoning by initiative of a small parcel of land. Furtherniore, the characterization analysis itself is flawed because it creates a false dichotomy between situations in which persons affected by an initiative are guaranteed due process of law regardless of the sizes of their individual interests, and those in which they are not. The nature of an official action should not alone determine the validity of the due process claims of those affected by it; yet the characterization analysis does just that when it is used to decide whether an imitiative is proper in a given case.

Where the public has an interest in using a procedure which cannot provide due process, the decision whether that interest overrides the affected parties' due process claims must take into account the strength of those claims. A balance must be struck; the weighing of several factors, rather than the drawing of a single line, is called for. Use of a balancing approach in deciding whether a land use choice may be made by the people serves the oft-expressed state interest in encouraging the initiative, as well as the equally important interest in safeguarding protected rights; the legislative-nonlegislative distinction, especially 
in the formalistic incarnation adopted by the Arnel inajority, serves neither master well.

Kathryn A. Dunwoody*

* B.A. 1980, Pomona College; third-year student, Boalt Hall School of Law, University of California, Berkeley. 